\title{
Hibriditas Medium pada Film Opera Jawa Karya Garin Nugroho sebagai Sebuah Dekonstruksi
}

\author{
Riksa Belasunda ${ }^{1}$, Acep Iwan Saidi² \& Iman Sudjudi \\ ${ }^{1}$ Sekolah Tinggi Seni Rupa dan Desain Indonesia (STISI) Telkom Bandung, Kawasan \\ Pendidikan Telkom, Jalan Telekomunikasi, Terusan Buah Batu Bandung, Indonesia \\ ${ }^{2}$ Fakultas Seni Rupa dan Desain, Institut Teknologi Bandung, \\ Jalan Ganesa No. 10 Bandung, Indonesia \\ Email: riksa@dkv.stisitelkom.ac.id
}

\begin{abstract}
Abstrak. Di tengah penyeragaman ide, gagasan, pesan, dan estetika pada filmfilm nasional, menarik menjadikan film Opera Jawa karya Garin Nugroho sebagai obyek penelitian sekaligus menjadi alasan kenapa penelitian ini dilakukan. Penelitian ini sebagai upaya peningkatan peran aktif produktif penonton dalam memahami dan memaknai teks film. Dengan fokus bagaimana pesan dan makna tersebut dibaca melalui elemen-elemen visual teks film yang dikonstruksi oleh keragaman penggunaan medium. Penelitian dilakukan dengan pendekatan estetika posmodern melalui metode semiotika dengan teknik deskriptif interpretatif. Membongkar struktur kode bahasa film, melalui analisis struktur dramatik naratif dan unsur pembentuk film, yang berkaitan dengan aspek non-verbal berupa tanda-tanda elemen visual dan gerak pada shot film. Elemen-elemen tersebut dikonstruksi oleh pilihan medium ungkap yang menjadi gaya ungkap (ekspresi) sineas dalam menyampaikan pesannya. Ekspresi sineas dalam menyampaikan ide gagasan, dan konsep tersebut, berupa idiom estetik parodi, dengan pelencengan makna, eksplorasi medium (hibriditas medium), dan gaya ungkap, sebagai kritik atau sindiran atas bentuk yang dijadikan rujukan. Lewat film ini, Garin Nugroho melakukan dekonstruksi terhadap tokoh-tokoh, ruang, pesan dan makna, serta narasi dari epik Ramayana karya Walmiki yang menjadi rujukannya. Merefleksikan persoalan gender, feminisme, dominasi maskulinitas, dominasi kekuasaan, pertentangan kelas, dan kapitalisme.
\end{abstract}

Kata kunci: hibriditas medium; semiotika film postmodern; dekonstruksi.

Abstract. In the midst of the ideas, concepts, messages, and aesthetics uniformity at national films, it is interesting to make Opera Jawa movie by Garin Nugroho the object of study. That is the reason why the study was conducted. The research was an effort to improve the audience's productive and active role in understanding and interpreting the subtitles by focusing on how to read the message and meaning through subtitles constructed by the diversity of the medium use. The study conducted with the postmodern aesthetic approach through semiotic method with descriptive interpretive technique dismantles the structure of the film code language through the analysis of narrative and dramatic structure-forming elements of the film. It deals with aspects such as non-verbal signs of visual elements and movement in the film shot. These elements are

Received July $2^{\text {nd }}, 2012$, Revised September $27^{\text {th }}, 2013$, Accepted for publication January $16^{\text {th }}, 2014$.

Copyright (C) 2014 Published by LPPM ITB, ISSN: 1978-3078, DOI: 10.5614/itbj.vad.2014.6.2.3 
constructed by the medium expression choice of the filmmaker in delivering his message. The filmmaker delivers his criticism or satire through swerved meaning and medium exploration (medium hybridism). Through this film, Garin Nugroho deconstructed the figures, space, message and meaning, as well as the narrative of the epic Ramayana by Walmiki as a reference. It reflects gender issues, feminism, masculinity domination, class warfare, and capitalism.

Keywords: medium hybridity; postmodern films Semiotics; deconstruction.

\section{$1 \quad$ Pendahuluan}

Kondisi perfilman nasional saat ini sedang mengalami kondisi aktual kontradiktif. Di satu sisi, pada film berbasis pop culture terjadi penyeragaman ide, gagasan, pesan, dan penggambaran estetika visualisasi film. Penonton film dengan basis ini, tinggi secara kuantitas dan relatif tidak memerlukan daya interpretatif tinggi yang rumit terhadap teks film, hal ini dikarenakan film populer ini mempunyai pola konvensional yang mudah dikenali dan dipahami penontonnya. Di sisi lain, film berbasis high culture, seperti halnya film Opera Jawa karya Garin Nugroho, lebih mementingkan misi (gagasan) sebagai alat untuk mencerdaskan "kultur" penontonnya serta menampilkan ekspresi sineas, akan tetapi dianggap tidak komunikatif, tidak mempunyai cerita yang jelas, dan tidak mengikuti teori film konvensional. Diperlukan upaya peningkatan peran aktif produktif penonton dalam memahami dan memaknai teks film berkaitan dengan eksplorasi penggunaan medium dalam film budaya tinggi tersebut. Dalam film Opera Jawa, cerita disajikan lewat penggabungan berbagai macam seni pertunjukan dan seni rupa seperti; seni tari jawa klasik dan kontemporer, seni musik jawa kontemporer, teater/opera, dan seni instalasi. Penggabungan beberapa medium seni tersebut memberikan kekuatan visual pada film ini dan membedakannya dari film-film nasional saat ini. Di sisi lain penggabungan medium di luar konvensi film pada umumnya tersebut membuat proses pemahaman terhadap cerita film ini tidak semudah memahami film-film pada umumnya.

Dalam upaya peningkatan peran aktif produktif penonton tersebut, Film Opera Jawa ini menarik untuk dijadikan obyek penelitian dan menjadi alasan penelitian ini dilakukan. Fokus penelitian dibatasi pada masalah pembacaan teks film yang berasal dari elemen-elemen visual, melalui kontribusi mediummedium yang digunakan dalam film tersebut.

\section{$2 \quad$ Hibriditas Medium}

Medium berasal dari bahasa Latin "medius" yang berarti tengah, perantara atau pengantar. Bentuk jamak dari medium adalah media. Melalui media inilah 
sebuah ide, gagasan, dan pesan disampaikan. Medium merupakan sarana yang digunakan pada sebuah sistem tanda atau kode bahasa - selanjutnya disebut sistem bahasa, dimana sistem tersebut dijalankan oleh aturan yang disepakati oleh semua anggota komunitas yang menggunakan bahasa tersebut. Sedangkan pilihan medium menjadi pilihan gaya ungkap. Komunitas film menyepakati medium yang digunakan dalam bahasa film terdiri dari visual, audio, gerak, dan verbal. Seni pertunjukan (performing art), secara umum terdiri seni pertunjukan teater, seni pertunjukan tari, dan seni pertunjukan musik [1]. Medium yang digunakan dalam seni pertunjukan tersebut mempunyai karakteristik yang khas dengan beberapa kesamaan dan perbedaan: (a) Medium pada seni teater terdiri dari; tatalaku (akting-gerak), tatarupa (visual), dan tatasuara (audio); (b) Medium pada seni tari terdiri dari tatagerak/kareografis, tatarupa (visual), dan tatasuara (audio); (c) Medium pada seni musik terdiri lagu/komposisi musikal (audio) dan tatarupa (visual). Medium pada senirupa terdiri dari visual dan ruang. Seni instalasi merupakan perkembangan dari salah satu teknik seni patung - asemblasi dan conceptual art. Seni instalasi mengalami perkembangan dalam penggunaan material dan teknologi, baik dalam medium visual, audio, ruang, dan gerak. Dalam proses petandaannya diutamakan ketertarikan dalam event produksi tanda dimana mediumnya sendiri sudah dianggap sebagai pesan.

Kesengajaan menyilangkan dan mempertemukan dua sistem bahasa atau gaya dalam satu dialog akan menghasilkan sistem bahasa atau gaya ketiga (baru) sebagai sistem bahasa atau gaya hibrida [2]. Dalam konteks medium, hibriditas medium merupakan penggabungan elemen-elemen medium yang berasal dari dua atau lebih sistem bahasa ke dalam satu sistem bahasa atau gaya ungkap baru. Sebagai akibat proses interpretasi ulang pada satu sistem bahasa atau kesepakatan tertentu yang ada sebelumnya, dimana elemen-elemen dari medium digabungkan dan dimodifikasi sedemikian rupa sehingga menghasilkan gaya ungkap yang baru. Hibriditas diawali ketika batasan-batasan yang ada pada sebuah sistem mengalami pelenturan, sehingga kejelasan dan ketegasan mengenai "kebenaran" universal mengalami pengaburan yang pada akhirnya menghasilkan suatu ruang baru, suatu sistem tersendiri. Pelenturan tersebut memiliki kecenderungan yang bertitik tolak pada hal-hal yang bersifat permukaan (imanen). Hibriditas sejalan dengan estetika posmodern dan tujuan dekonstruksi yakni mendestabilisasikan hal-hal yang sudah mapan, dan merekonstruksikannya kembali menjadi hal baru dan terbuka menjadi banyak kemungkinan termasuk kemungkinan yang bersifat kontradiktif dengan prinsipprinsip sistem bahasa atau gaya sebelumnya [3].

\section{Dekonstruksi}

Gerakan filsafat postrukturalisme berkembang seiring dengan gerakan kebudayaan posmodernisme yang dicirikan oleh penentangan terhadap 
totalitarianisme dan universalisme. Jacques Derrida mengkritik tradisi filsafat dan linguistik barat tersebut dengan memusatkan pemikiran filsafat dekonstruktivisme-sebagai istilah yang digunakan untuk menerangkan satu kategori estetik atau gaya posmodernisme-pada kemustahilan makna dari sebuah teks [2]. Dekonstruksi yang dikembangkan Jacques Derrida menekankan pentingnya bahasa tulisan (penanda) dan ketertarikan seorang desainer (kreator) kepada visual atau elemen-elemen grafis mencerminkan sebuah dekonstruksi [4] . Dekonstruksi berarti memisahkan, membongkar untuk menemukan dan menelanjangi berbagai asumsi, strategi teoritis dan ruang kosong teks. Pembongkaran struktur kode bahasa dilakukan dengan memecahnya menjadi komponen-komponen (penanda-penanda) dan merekonstruksinya kembali dengan kemungkinan-kemungkinan baru untuk mendapatkan hasil akhir. Tujuan dekonstruksi untuk destabilisasikan hal-hal yang sudah mapan untuk menandainya sebagai hal yang berguna, perlu, tidak tepat, dan sekaligus keliru [5]. Masalah utama dalam dekonstruksi adalah pada saat mendekonstruksi sebuah teks, ia menggunakan bahasa konseptualnya sendiri.

\section{$4 \quad$ Metode Penelitian}

Penelitian ini dilakukan dengan pendekatan estetika posmodern melalui metode semiotika dengan teknik deskriptif interpretatif. Metoda ini digunakan untuk memaknai teks film terutama yang berupa elemen atau tanda-tanda visualkarakter, setting, properti, dan gerak, yang terdapat pada shot sebuah film.

\subsection{Tahapan Penelitian}

Analisis dilakukan terhadap unsur terkecil dari teks naratif sebuah film berupa shot. Unsur-unsur tersebut berupa elemen-elemen visual disamping audio serta unsur naratif verbal yang berbentuk monolog dan dialog. Unsur verbal tersebut diposisikan sebagai jangkar (anchor) untuk mengikat dan mengarahkan konotasi dalam proses produksi makna. Tahapan penelitian dilakukan sebagai berikut: (a) analisis narasi, dilakukan terhadap cerita, plot, dan struktur; (b) analisis struktur, terutama dilakukan terhadap elemen atau tanda-tanda visual yang dikonstruksi oleh elaborasi medium-medium yang menjadi gaya ungkap kreator film; (c) pembacaan semiotika, dilakukan untuk mengungkap pesan dan makna dari teks film yang berupa tanda-tanda visual dalam bentuk karakter, setting, properti, dan gerak. Serta upaya menemukan jejak makna (trace) dari sebuah teks dan melahirkan jejak baru dibalik makna tersebut melalui pendekatan dekonstruksi. 


\subsection{Prosedur Pengambilan Data}

\subsubsection{Jenis dan Sumber Data}

Sumber data primer: Film Opera Jawa format DVD.

Jenis data yang dianalisa adalah tanda-tanda dari unsur-unsur naratif dan sinematik sebuah shot film, terutama visual dan dukungan audio dan verbal.

\subsubsection{Sumber Data Sekunder}

Berasal dari berbagai studi kepustakaan berupa buku referensi, data yang diperoleh dari literatur pendukung seperti esai dan artikel-artikel hasil penelitian. Teori-teori tentang film, semiotika, semiotika film, estetika posmodern, pos strukturalis, cultural studies, dekonstruksi, intertekstualitas, hibriditas, ideologi, hegemoni, seni pertunjukan, dan seni instalasi. Pengumpulan data dan informasi juga diperoleh melalui wawancara, media internet dan sumber-sumber informasi lainnya.

\subsubsection{Teknik Pengumpulan Data}

Pengumpulan data dilakukan dengan cara mengamati langsung sumber data primer dan penelaahan terhadap data sekunder.

\section{Dekonstruksi Medium Pada Film Opera Jawa}

Medium merupakan sarana yang digunakan pada sebuah kode bahasa. Dalam kode bahasa film, medium-medium yang digunakan terdiri dari medium verbal dan medium non-verbal. Medium verbal terdiri dari elemen-elemen monolog, dialog, dan terkadang digunakan juga Subtitle. Medium non-verbal terdiri dari elemen-elemen visual, gerak, dan audio. Elemen visual terdiri dari setting, properti, kostum (wardrobe) dan make-up. Elemen gerak terdiri dari akting dan koreografi. Elemen audio yang merupakan film score terdiri dari komposisi musik latar dan efek suara.

Pada film Opera Jawa ini, sebagian setting dan properti diungkapkan melalui medium seni instalasi, sementara kostum dan make-up mengacu kepada kehidupan sehari-hari dalam konteks budaya masyarakat Jawa (Yogyakarta-

Solo) kontemporer. Akting pemeran sebagian besar diungkapkan melalui medium dramatisasi gerak (akting teatrikal) dan koreografi tari serta sebagian lainnya diungkapkan melalui gerak natural. Koreografi diungkapkan melalui seni tari Jawa (dan sebagian kecil tari Bali) tradisional dan kontemporer. Monolog, dialog dan komposisi musik latar diungkapkan melalui medium seni musik (karawitan) berupa instrumentalisasi (gamelan) dan vokalisasi (tembang). 
Melalui konstruksi medium-medium tersebut di atas, ide, gagasan, dan pesan disampaikan oleh sineas. Ide, gagasan, dan pesan tadi disampaikan melalui unit terkecil sistem bahasa film berupa shot. Pokok pikiran (subjek) dari ide dan gagasan secara utuh disampaikan melalui sebuah adegan. Konstruksi medium tersebut dapat dilihat pada Tabel 1.

Tabel 1 Konstruksi medium dalam kode bahasa film Opera Jawa.

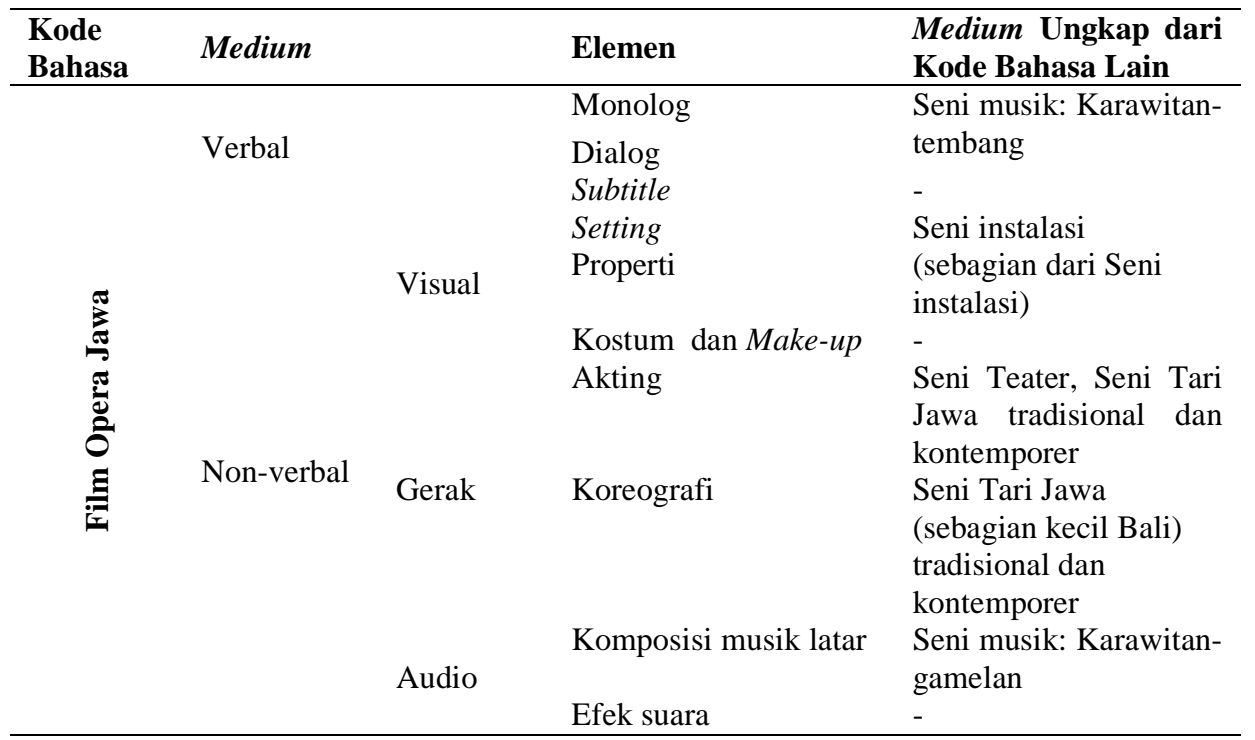

Semua pelibat produksi Film ini mempunyai peranan sebagai kreator yang menginterpretasikan naskah - yang ditulis sendiri oleh Garin Nugroho dan Armantono, juga bekerja di bawah pengarahan Garin sebagai sutradara. Di samping menginterpretasi naskah pelibat produksi juga memproduksi penggunaan tanda dan kode bahasa sesuai dengan kepakarannya masing-masing melalui medium pilihannya. Garin melakukan kolaborasi dengan koreografer (Eko Supriyanto dan Martinus Miroto), seniman-seniman instalasi (Sunaryo, Agus Suwage, Entang Wiharso, Hendro Suseno, Nindityo Adipurnomo, S Teddy D, dan Tita Rubi), seniman musik (Rahayu Supanggah), perancang busana (Samuel Watimena), aktor dan aktris (Artika Sari Devi, Retno Maruti, dan Slamet Gundono), serta kameramen (director of photography) yang dipercayakan kepada Teoh Gay Hian. Bentuk kolaborasi ini berada dalam kaidah-kaidah seni pertunjukan dan seni rupa. Seni pertunjukan dalam film ini terdiri dari teater, tari, wayang, seni musik (karawitan), dan seni rupa (seni instalasi). Cabang seni tersebut mempunyai kekuasaan artistik, penafsiran dan titik berat dalam konvensi kode bahasa dan ungkapan medianya masing-masing. 
Selain perbedaan karakteristik tadi, masing-masing kode bahasa mempunyai beberapa persamaan pada medium ungkapnya (visual, gerak, audio, dan ruang).

Garin memberikan keleluasaan interpretatif pada naskah dan memberikan ruang bagi ketertarikan atas event produksi tanda kepada pelibat produksi, sehingga medium yang digunakannya sudah menjadi pesan dan identitas gaya ungkap Film ini. Kode-kode bahasa di luar kode bahasa film yang diungkap dalam medium film saling memperkuat dan melengkapi kode bahasa film ini. Interpretasi naskah dan event produksi tanda dari semua pelibat produksi diorganisasikan dan melebur dalam bingkai mata kamera sesuai interpretasisubyektif sutradara - yang interpretasi oleh kameramen dalam bentuk shot sebagai satuan unit terkecil film. Sutradara melakukan penilaian dan memberikan keputusan akhir atas mutu pekerjaan seluruh unit pelibat produksi baik secara teknis maupun artistik. Pada bagian akhir sutradara mengarahkan penyunting gambar dan penata musik dalam rangkaian shot-adegan-sekuen, serta memberi penilaian dan keputusan akhir atas kualitas karya dalam bentuk "release copy". Apa yang ada dalam "release copy" itulah yang akan nampak di layar (screen), yang menjadi sebuah tontonan. Film Opera Jawa menjadi sebuah karya penuturan sinematik dengan gaya ungkap artistik dan narasi dramatik Garin sang sutradara.

Bentuk sebuah film berupa elemen-elemen visual, merupakan permainan bebas penanda dan kode personal kreator yang menjadi bahasa ungkap dan gaya bertutur personal kreator. Pada film Opera Jawa, elemen visual yang berasal dari medium seni instalasi dalam rupa penanda metafora dibuat untuk memaknai ruang fisik (konkrit), ruang batin (imajiner), dan perlintasan di antara kedua ruang tersebut. Sebagian dari penanda metafora yang ada dalam film Opera Jawa ini diciptakan kreator dengan metafora eufemistis, sebagai pengganti asosiasi yang kasar, kejam, atau asosiasi lain yang tidak menyenangkan degan istilah atau frase (simbol) yang lebih halus dan tidak menyinggung [6]. Elemen visual yang berasal dari medium gerak berupa gerak teatrikal dan tari tradisional-kontemporer selain dibuat untuk dramatisasi adegan (termasuk mendukung perlintasan ruang fisik - imajiner) juga sebagian medium gerak bersifat eufemistis. Pemaknaan dari penanda-penanda metafora baik yang berasal dari medium visual dan gerak bersifat sulit atau tidak mudah dipahami (elutif), sehingga terjadi kemungkinkan ketidakberhinggaan makna. 
Berikut gambaran bagaimana pilihan medium-medium ungkap berupa medium visual dan gerak sebagai gaya ungkap sineas berinteraksi mengkonstruksi pesan dan makna dalam film Opera Jawa. Pilihan medium sebagai gaya ungkap sineas tersebut dapat dilihat pada Gambar 1.

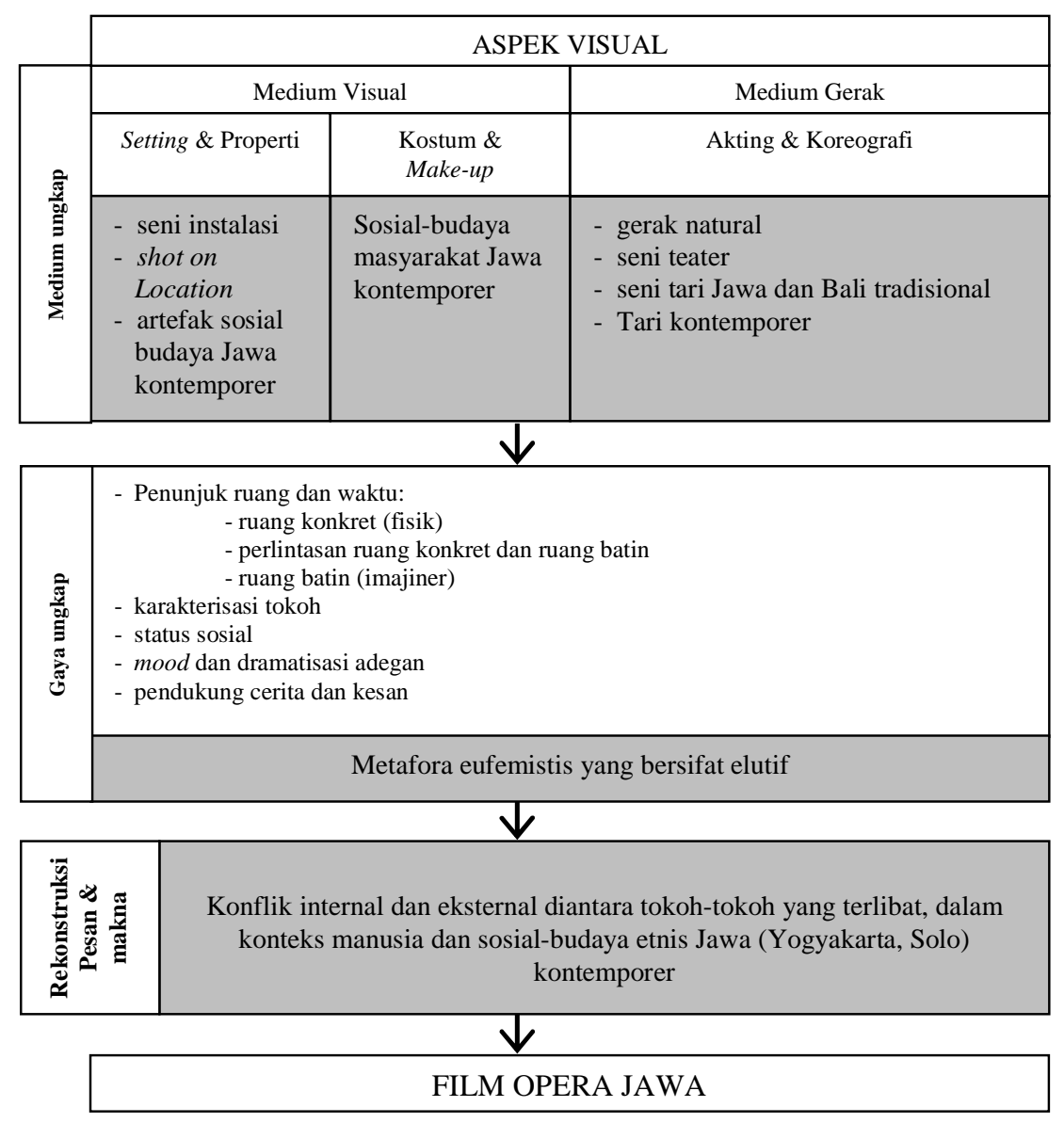

Gambar 1 Pilihan medium sebagai gaya ungkap sineas dalam film Opera Jawa.

\section{Dekonstruksi Terhadap Pesan dan Makna dalam Film Opera Jawa}

Pembacaan film Opera Jawa merupakan salah satu upaya memahami, memaknai, dan mengapresiasi karya film dalam peningkatan peran aktif dan produktif penonton film. Berdasarkan fase analisis berkaitan dengan struktur dan unsur pembentuk film serta pilihan medium-medium ungkap oleh sineas. 
Pilihan medium-medium ungkap menjadi gaya ungkap sineas dalam mengkonstruksi pesan dan makna yang hendak dikomunikasikan sineas kepada penonton filmnya. Pada fase sintesis dalam memaknai dan memahami pesan film Opera Jawa ini tidak terlepas dari konteks sosial-budaya Jawa kontemporer sebagai rujukan (referensi).

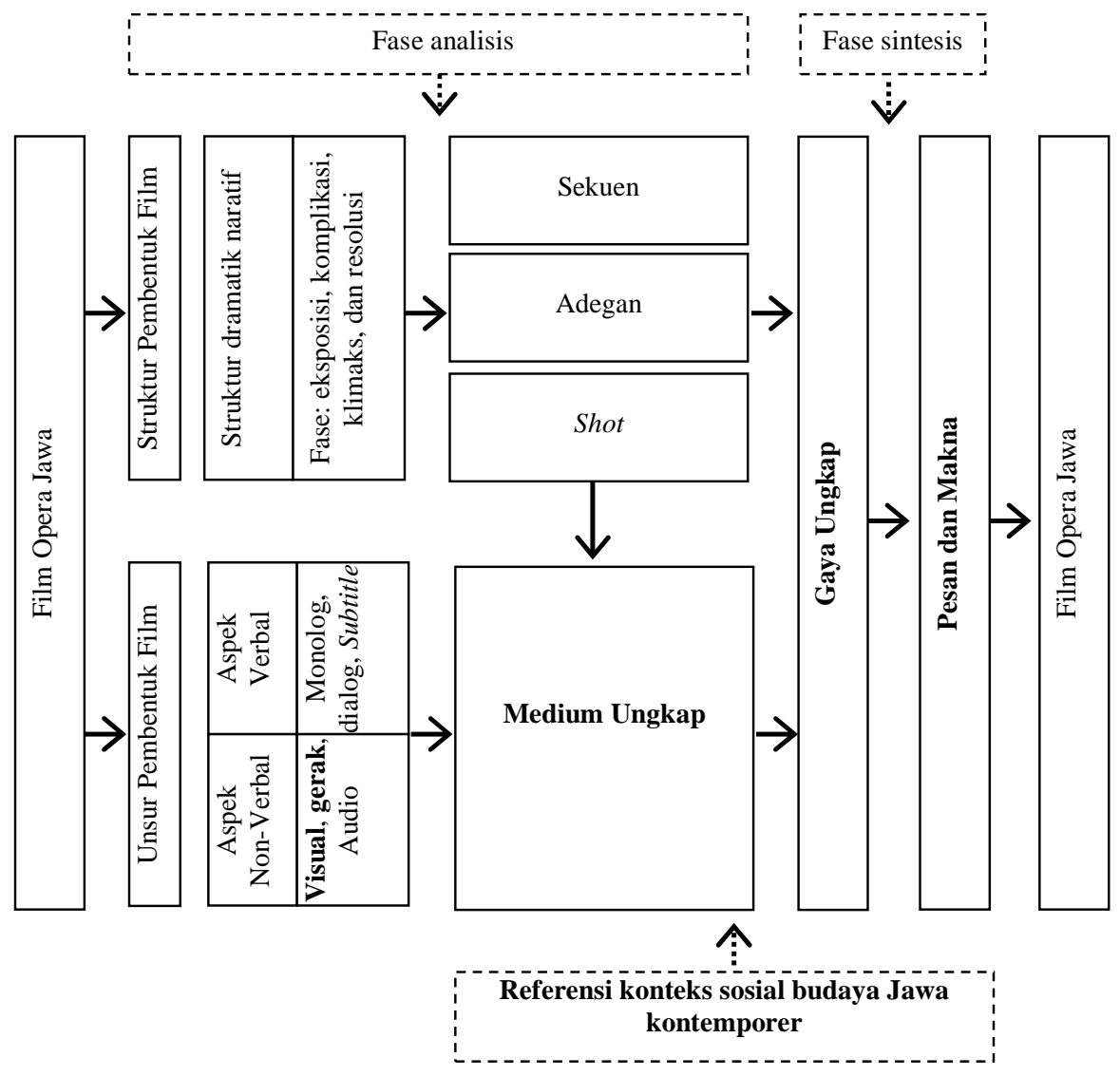

Gambar 2 Sistem pembacaan film Opera Jawa.

Sampel yang dianalisis adalah: (1) adegan 4: sekuen 3: fase eksposisi (F1:S3:A4), (2) adegan 3: sekuen 4: fase komplikasi (F2:S4:A3), (3) adegan 7: sekuen 6: fase komplikasi (F2:S6:A7), (4) adegan 3: sekuen 8: fase klimaks (F3:S8:A3), (5) adegan 4: sekuen 9: fase klimaks (F3:S9:A4), (6) adegan 2: sekuen 10: fase resolusi (F4:S10:A2). 
Sampel dianalisis melalui sistem pembacaan film Opera Jawa, dapat dilihat pada Gambar 2.

Sebagai sebuah contoh implementasi sistem pembacaan untuk pembacaan pesan dan makna ini dilakukan pada salah satu sampel adegan yang dianalisis, yaitu adegan 4: sekuen 3: fase eksposisi (F1:S3:A4) seperti dijelaskan pada Tabel 2.

Tabel 2 Kajian elemen-elemen visual pada F1:S3:A4.

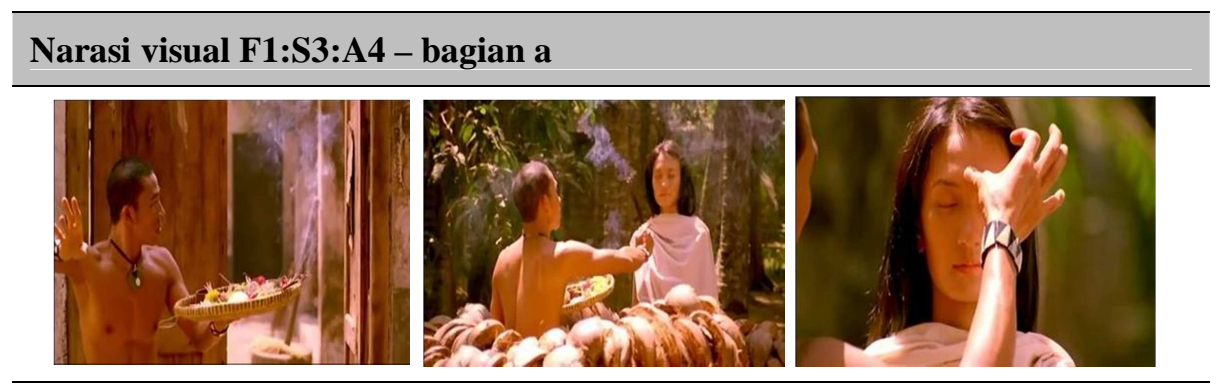

\section{Elemen Visual}
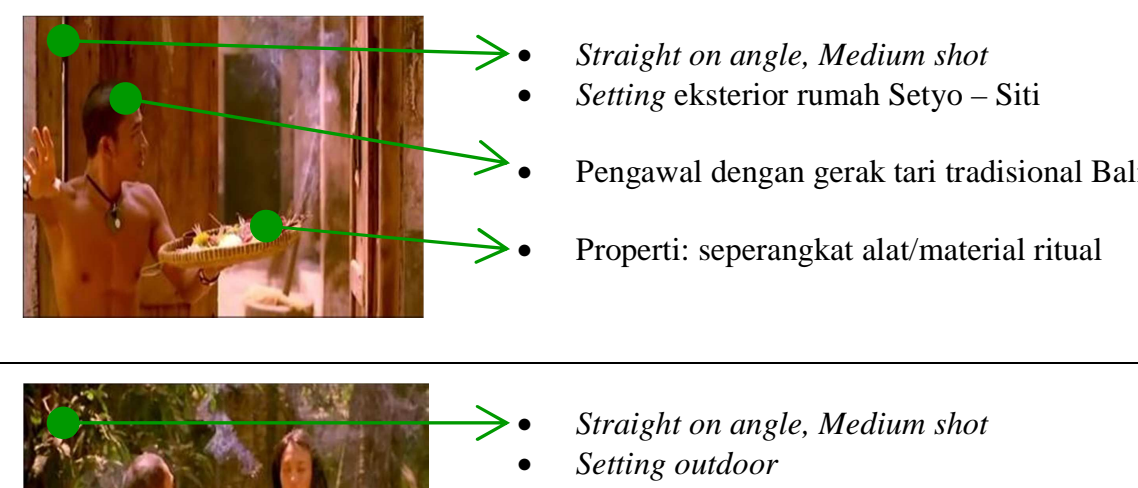

- Setting outdoor

Siti berdiri berhadapan dengan pengawal dengan pakaian penutup dada, gerak natural

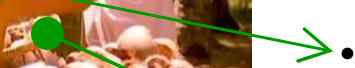
Pengawal mendekati Siti untuk melakukan adegan ritual dengan gerak tari tradisional Bali

Properti: seperangkat alat/material ritual, tumpukan sabut kelapa 


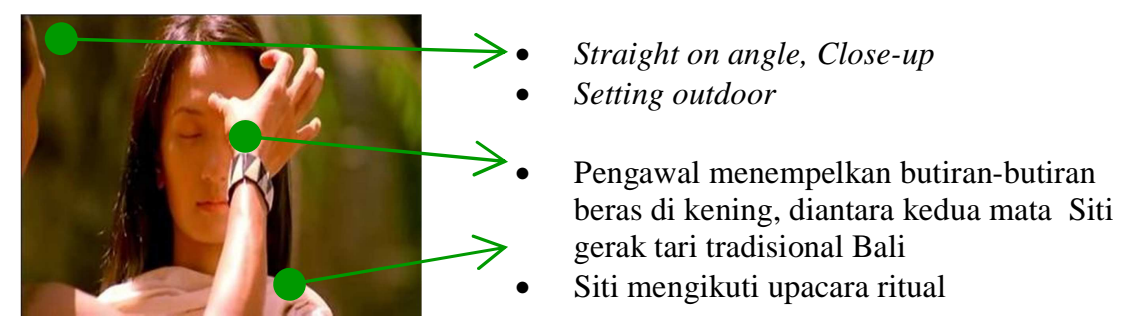

\section{Medium ungkap}

Medium Visual

Medium Gerak

- $\quad$ Setting eksterior rumah dan outdoor

- Properti: seperangkat alat/material ritual; butiran beras; tumpukan sabut kelapa; kain penutup dada berwarna putih
- $\quad$ Siti diam, tak bergerak

- Pengawal dengan gerak natural dan tari tradisional Bali

\section{Relasi antar medium sebagai gaya ungkap}

Setting eksterior rumah Setyo-Siti menjadi penunjuk ruang sosial (kongkrit), tumpukan sabut kelapa - dianggap sebagai petanda kehidupan, karena semua bagian pohon kelapa dianggap berguna bagi kehidupan masyarakat budaya Jawa, menjadi penunjuk ruang imajiner dan status sosial dimana Siti berada.

Kostum dan kain putih penutup dada yang dikenakan Siti, perangkat alat dan kelengkapan upacara ritual (butiran beras, bunga), dan gerak tari Pengawal menjadi penunjuk dilakukannya upacara ritual Mawija.

\section{Pesan dan Makna}

\section{Pesan:}

Upaya menghadapi masalah dengan lebih jernih.

Pada kepercayaan Hindu Bali, upacara ritual Mawija adalah upaya menumbuhkembangkan benih-benih sifat kedewaan (Siwa) untuk mengatasi sifat-sifat keraksasaan yang tumbuh dan berkembang dalam pikiran dan hati manusia. Pada upacara ini butiran beras ditempelkan di atas kening diantara mata dan menelan sebagian butir beras lainnya. Upacara ini sekaligus untuk penyucian diri [7]. Pada adegan ini hanya diperlihatkan penempelan butir beras diatas kening Siti, menjadi penunjuk upaya memperkuat dan mengedepankan pikiran kedewaan (pikiran baik dan jernih) dalam menghadapi kehidupan. 

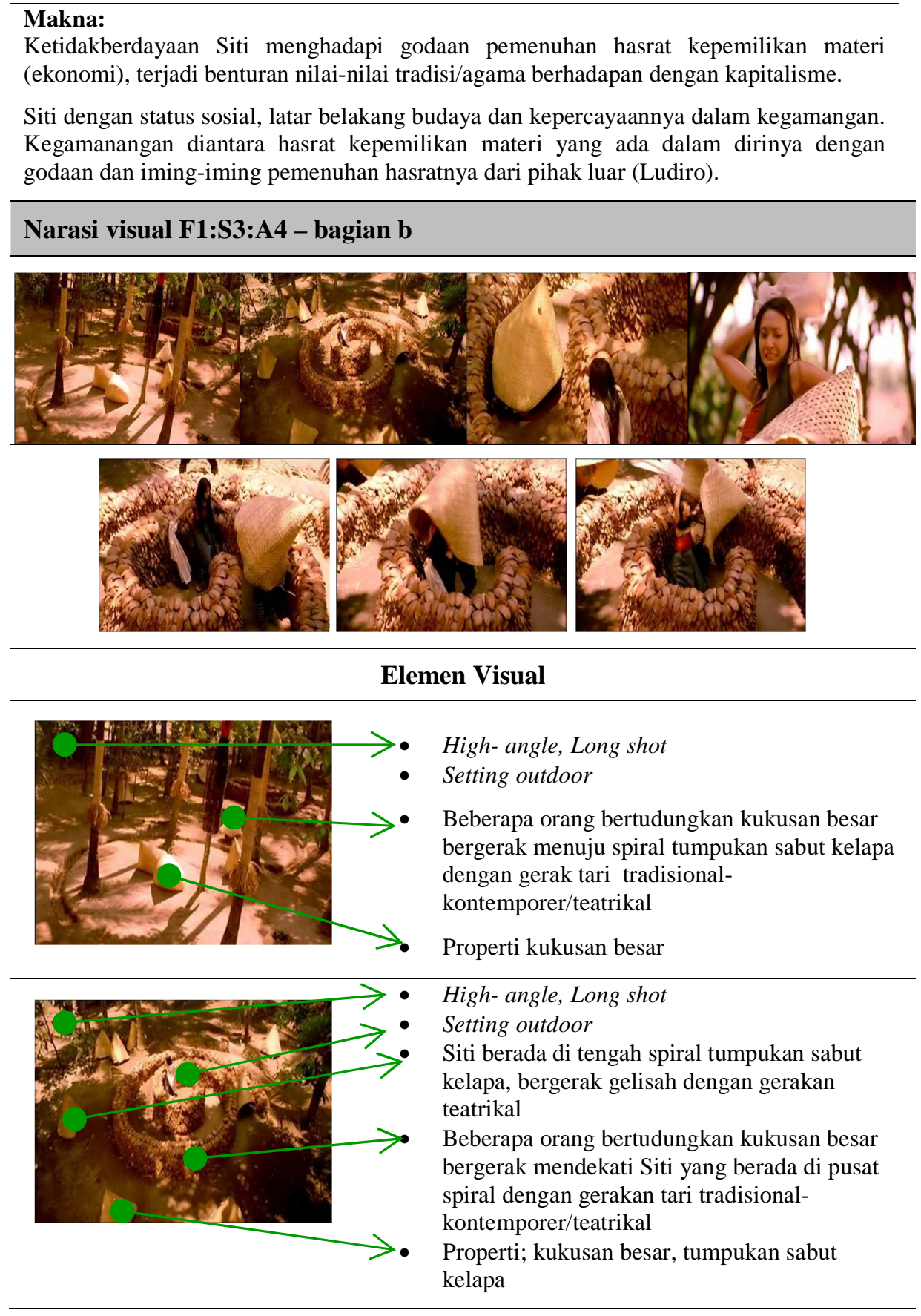

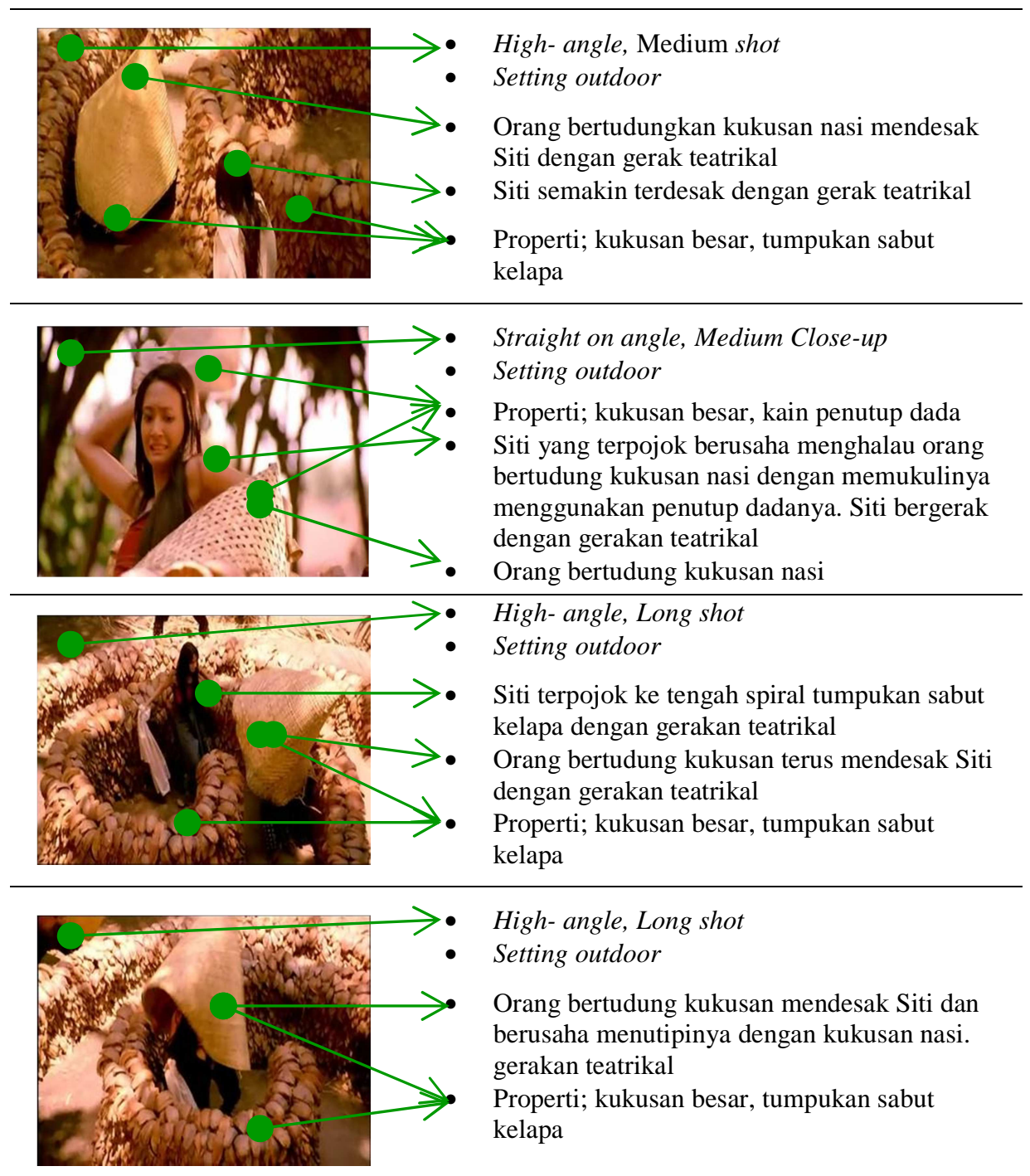

High- angle, Long shot

- Setting outdoor

Orang bertudung kukusan mendesak Siti dan berusaha menutipinya dengan kukusan nasi. gerakan teatrikal

Properti; kukusan besar, tumpukan sabut kelapa

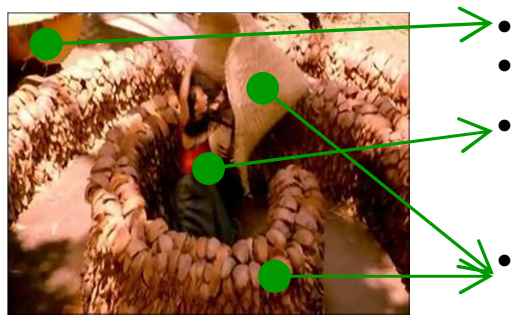

High- angle, Long shot

- Setting outdoor

Siti berusaha untuk melepaskan diri dari kungkungan orang bertudungkan kukusan nasi besar, dengan gerakan teatrikal

Properti; kukusan besar, tumpukan sabut kelapa 


\section{Medium ungkap}

\section{Medium Visual Medium Gerak}

- $\quad$ Setting oudoor

- Properti: kukusan nasi berukuran besar; tumpukan sabut kelapa membentuk spiral; kain penutup dada berwarna putih
- Sejumlah orang bertudungkan kukusan nasi dengan gerakan tari tradisional kontemporer dan teatrikal

- Siti terpojok dan berusaha membebaskan diri dari kungkungan orang bertudugkan kukusan nasi, dengan gerakan teatrikal

\section{Relasi antar medium sebagai gaya ungkap}

Setting outdoor, tidak merujuk kepada satu lokasi spesifik. Tumpukan sabut kelapa berbentuk spiral. Spiral merupakan simbol visual untuk perjalanan hidup yang berkembang; evolusi lahir batin; keseimbangan dan pemusatan pikiran [8].

Kukusan nasi berukuran besar menjadi penanda besarnya hasrat penguasaan/kepemilikan materi. Orang-orang dengan bertudungkan kukusan nasi berukuran besar menjadi pertanda kekuatan hasrat kepemilikan material.

Kain penutup dada berwarna putih menjadi petanda kekuatan nilai-nilai moral yang dimiliki Siti. Sudut pandang kamera (high-angle) memberi penegasan kondisi yang menekan Siti.

Gerak tari tradisional-kontemporer dan teatrikal menjadi elemen dramatisasi adegan.

\section{Pesan dan Makna}

\section{Pesan:}

Upaya melawan hasrat kepemilikan materi.

Pada ujung spiral tumpukan sabut kelapa Siti terpojok dan berusaha melawan dan mengusir orang-orang bertudungkan kukusan nasi besar yang mencoba menutupinya dengan kukusan nasi menggunakan kain putih penutup dada. Ujung spiral tumpukan sabut kelapa menjadi petanda ujung kebuntuan pikir pada evolusi dan perjalanan hidup Siti [8]. Kain putih penutup dada Kain penutup dada berwarna putih menjadi petanda kekuatan nilai-nilai moral yang dimiliki Siti. Warna putih melambangkan kesucian, polos, jujur, dan murni [9]. Melawan dominasi orang-orang yang bertudungkan kukusan nasi menjadi pertanda upaya melawan hasrat kepemilikan materi dengan berpikir jernih dan kekuatan nilai-nilai moral yang dimiliki.

\section{Makna:}

Pertarungan terjadi dalam diri Siti, antara pikiran jernih dan nilai-nilai moral yang dimiliki melawan hasrat pemilikan materinya sendiri. Terjadi pertentangan diantara nilai-nilai tradisi/moral/agama yang dijalaninya dengan godaan hasrat pemilikan materi yang merupakan refleksi hegemoni kapitalisme yang mengiming-iminginya. 

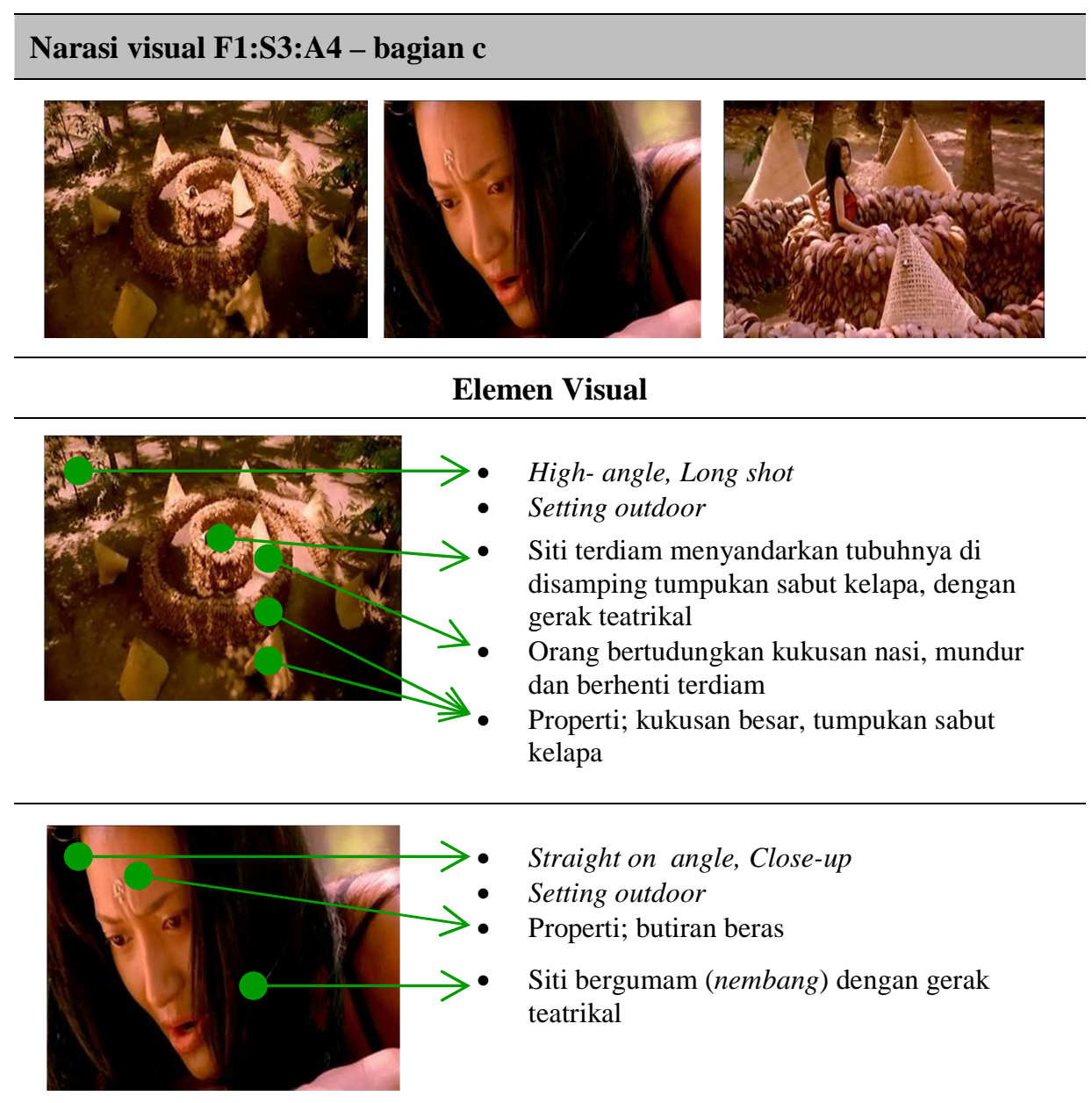

- Straight on angle, Close-up

- Setting outdoor

- Properti; butiran beras

Siti bergumam (nembang) dengan gerak teatrikal

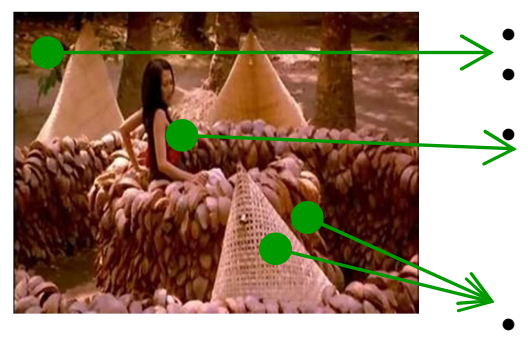

- $\quad$ Straight on angle, Medium Long shot

- Setting outdoor

Siti, berada di tengah spiral menyandarkan dirinya di samping tumpukan sabut sambil memperhatikan orang-orang bertudungkan kukusan nasi, bergerak gelisah dengan gerakan teatrikal

- Properti; kukusan besar, tumpukan sabut kelapa 
Medium ungkap

\section{Medium Visual Medium Gerak}

- $\quad$ Setting oudoor

- Properti: kukusan nasi berukuran besar; tumpukan sabut kelapa membentuk spiral; butiran beras
- Sejumlah orang bertudungkan kukusan nasi diam tidak bergerak.

- $\quad$ Siti terdiam dan bergerak gelisah di ujung spiral tumpukan sabut kelapa dengan gerak teatrikal.

\section{Relasi antar medium sebagai gaya ungkap}

Setting outdoor, tidak merujuk kepada satu lokasi spesifik. Tumpukan sabut kelapa berbentuk spiral. Spiral merupakan simbol visual untuk perjalanan hidup yang berkembang; evolusi lahir batin; keseimbangan dan pemusatan pikiran. Kukusan nasi berukuran besar menjadi penanda besarnya hasrat penguasaan/kepemilikan materi. Orangorang dengan bertudungkan kukusan nasi berukuran besar menjadi pertanda kekuatan hasrat kepemilikan material.

Butiran beras di kening Siti menunjukkan upayanya untuk melihat persoalan/masalah secara lebih jernih. Sudut pandang kamera (high-angle) memberi penegasan kondisi yang menekan Siti. Jarak kamera (close-up) memperlihatkan mimik (ekspresi) kebingungan

Diam dan gerak teatrikal menjadi elemen dramatisasi adegan.

\section{Pesan dan Makna}

\section{Pesan:}

Siti dalam kebingungan. Siti mempertanyakan upaya dirinya dalam melawan hasrat kepemilikan material. Dia merasa tidak mampu membedakan hal yang benar dari yang salah, tidak mampu melihat permasalah lebih jernih lagi.

\section{Makna:}

Siti merasa tidak berdaya melawan hasratnya sendiri. Siti gelisah terpojok dalam pergulatan batinnya sendiri. Di satu sisi secara individu, dia menginginkan pemenuhan hasrat pemilikan materi, di sisi lain hasrat itu tidak dia dapatkan dari suaminya Setyo. Dalam kehidupan sosial sebuah keluarga pada budaya Jawa kontemporer, seorang istri lebih banyak mengikuti dan menerima apa yang diperolehnya dari suaminya, dengan posisi utama laki-laki sebagai pencari nafkah. 


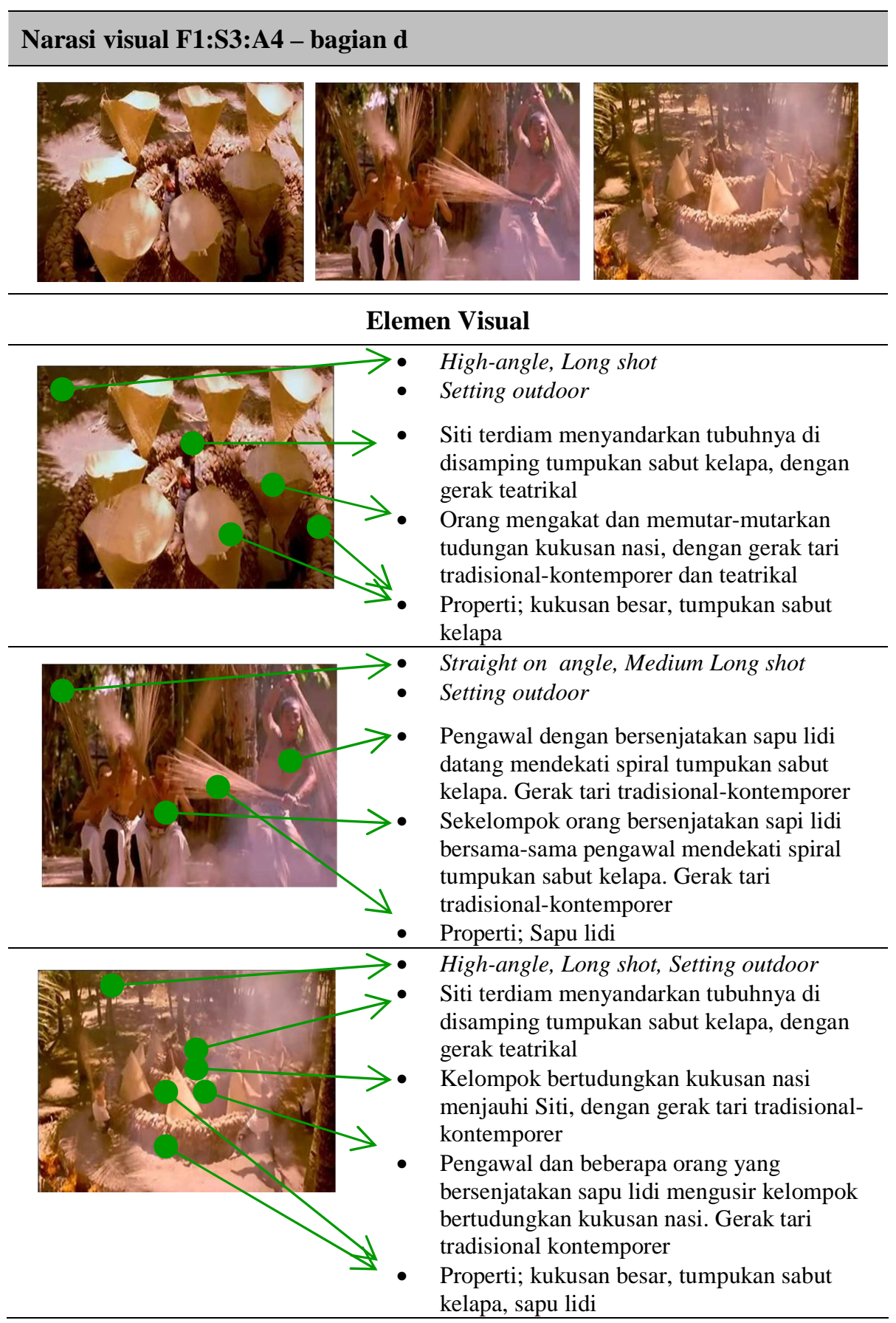




\section{Medium ungkap}

\section{Medium Visual}

- $\quad$ Setting oudoor

- Properti: kukusan nasi berukuran besar; tumpukan sabut kelapa membentuk spiral; sapu lidi

\section{Medium Gerak}

- Sejumlah orang bertudungkan kukusan nasi bergerak menarik perhatian dan meninggalkan ujung spiral sabut kelapa dengan gerak tari tradisional-kontemporer.

- Siti bergerak gelisah di ujung spiral tumpukan sabut kelapa dengan gerak teatrikal.

- Kelompok pengawal mengusir kelompok bertudungkan kukusan nasi menjauhi dan meninggalkan Siti di ujung spiral tumpukan sabut kelapa dengan gerak tari tradisionalkontemporer

\section{Relasi antar medium sebagai gaya ungkap}

Setting outdoor, tidak merujuk kepada satu lokasi spesifik. Tumpukan sabut kelapa berbentuk spiral. Spiral merupakan simbol visual untuk perjalanan hidup yang berkembang; evolusi lahir batin; keseimbangan dan pemusatan pikiran. Kukusan nasi berukuran besar menjadi penanda besarnya hasrat penguasaan/kepemilikan materi. Orang-orang dengan bertudungkan kukusan nasi berukuran besar menjadi pertanda kekuatan hasrat kepemilikan material. Sapu lidi dalam masyarakat Jawa digunakan sebagai alat untuk menyapu dan membersihkan yang kotor. Sapu lidi menjadi petanda kekuatan nilai-nilai moral yang akan membantu membersihkan kejernihan melihat, berpikir dan bertindak. Kain putih yang dikenakan pengawal dan pasukannya menjadi pertanda nilai-nilai kebaikan/moral yang dibawa mereka. Sudut pandang kamera (highangle) memberi penegasan kondisi yang menekan Siti.

Gerak tari tradisional-kontemporer dan gerak teatrikal menjadi elemen dramatisasi adegan.

\section{Pesan dan Makna}

Pesan:

Nilai moral/agama dapat memberikan pertolongan bagi mereka yang membutuhkannya. Nilai-nilai moral/agama yang direpresentasikan oleh pengawal dan kelompoknya memberikan pertolongan kepada Siti yang kebigungan dan tidak berdaya supaya bisa terbebas dari kuatnya desakan dan iming-iming hasrat pemilikan materi.

\section{Makna:}

Kembali ke nilai-nilai moral tradisional, karena nilai-nilai moral ini dianggap mampu mengatasi persoalan kehidupan manusia (masyarakat) dengan latar belakang sosial budaya tradisional dari kuatnya iming-iming hasrat pemilikan materi yang merupakan refleksi hegemoni kapitalisme. Nilai-nilai moral ini masih dianggap sebagai benteng kuat untuk melindungi masyarakat dengan latar belakang sosial budaya tradisional. 
Pada adegan F1-S3-A4 ini, dapat dibaca dekonstruksi: (a) pesan dan makna, dimana terjadi benturan antara nilai budaya/tradisi/agama/moral dengan nilai kapitalisme dalam diri tokoh Siti; (b) tokoh, dimana Siti berada dalam kebimbangan diantara mengikuti kata hati atau tetap berada pada nilai-nilai tradisi/budaya/agama dalam pemenuhan hasrat pemilikan materi. Tokoh Pengawal menjadi penjaga moral bagi Siti; (c) ruang, dimana terjadi perpindahan dari ruang konkrit ke ruang batin (imajiner); (d) narasi, dimana tokoh Siti melakukan upacara tradisi/agama Mawija agar dapat melihat dengan jernih dan mendapat dukungan kekuatan moral dari Pengawal untuk melawan bujukan hasrat pemilikan materi (kapitalisme).

Dari semua sampel yang dianalisis dapat dibaca dekonstruksi terhadap pesan dan makna dari cerita Ramayana yang menjadi rujukannya, dapat dilihat pada Tabel 3 .

Tabel 3 Dekonstruksi terhadap pesan dan makna pada film Opera Jawa.

\begin{tabular}{ll}
\hline \multicolumn{1}{c}{ Ramayana karya Walmiki } & \multicolumn{1}{c}{ Opera Jawa karya Garin Nugroho } \\
\hline $\begin{array}{l}\text { Konteks Hindu India pada abad ke-4 } \\
\text { sebelum Masehi }\end{array}$ & Konteks budaya Jawa kontemporer \\
Integritas tokoh-tokoh yang terlibat & $\begin{array}{l}\text { Ekspresi ironik berupa hal-hal atau sifat } \\
\text { yang saling berlawanan pada diri tokoh- } \\
\text { tokoh yang terlibat }\end{array}$ \\
$\begin{array}{l}\text { Keteladanan, sifat ksatria, berlaku adil } \\
\text { dan bijaksana dalam menumpas }\end{array}$ & $\begin{array}{l}\text { Ketidakberdayaan dalam dominasi } \\
\text { kekuasaan pada pertentangan kelas dan } \\
\text { dominasi kekuasaan pada tokoh Rama } \\
\text { ketidakmampuan pemenuhan hasrat } \\
\text { (ekonomi, kesenangan, dan birahi) yang } \\
\text { diinginkan istrinya pada tokoh Setio }\end{array}$ \\
$\begin{array}{l}\text { Integritas dan kesetiaan seorang istri } \\
\text { dalam lembaga perkawinan patriarkal } \\
\text { dengan motif kepentingan yang } \\
\text { sederhana, pada tokoh Sinta }\end{array}$ & $\begin{array}{l}\text { Kecenderungan feminisme, persoalan } \\
\text { gender yang menggugat dominasi } \\
\text { maskulinitas dan pengembaraan pemenuhan } \\
\text { hasrat (ekonomi, kesenangan, dan birahi) } \\
\text { pada tokoh Siti. }\end{array}$ \\
$\begin{array}{l}\text { Konflik eksternal pada tokoh-tokoh yang } \\
\text { terlibat, merefleksikan persoalan gender, } \\
\text { dan dominasi kekuasaan }\end{array}$ & $\begin{array}{l}\text { Konflik eksternal pada tokoh-tokoh yang } \\
\text { terlibat, merefleksikan persoalan gender, } \\
\text { feminisme, kapitalisme, pertentangan kelas } \\
\text { dan dominasi kekuasaan }\end{array}$ \\
\hline
\end{tabular}

Juga dekonstruksi terhadap narasi cerita rujukannya, dapat dilihat pada Tabel 4. 
Tabel 4 Dekonstruksi terhadap narasi pada film Opera Jawa.

\begin{tabular}{|c|c|}
\hline Ramayana karya Walmiki & Opera Jawa karya Garin Nugroho \\
\hline $\begin{array}{l}\text { Berdasarkan epik Ramayana yang ditulis } \\
\text { oleh Resi Walmiki pada abad ke-4 } \\
\text { sebelum Masehi. Terdapat } 7 \text { kitab; } \\
\text { Balakanda, Ayodhyakanda, } \\
\text { Aranyakakanda, Kiskhindakanda, } \\
\text { Sundarakanda, Yudhakanda, dan } \\
\text { Uttarakanda. }\end{array}$ & $\begin{array}{l}\text { Berdasarkan naskah film (screenplay) yang } \\
\text { ditulis oleh Garin Nugroho dan Armanto, } \\
\text { diproduksi tahun 2006. Hanya berdasarkan } \\
4 \text { kitab dasar; Ayodhyakanda, } \\
\text { Aranyakakanda, Yudhakanda, dan } \\
\text { Uttarakanda. }\end{array}$ \\
\hline $\begin{array}{l}\text { Setting dan latar belakang status sosial } \\
\text { raja-raja pada kerajaan Hindu India- } \\
\text { Alengka pada abad ke- } 4 \text { sebelum } \\
\text { Masehi. }\end{array}$ & $\begin{array}{l}\text { Setting dan latar belakang status sosial } \\
\text { masyarakat Jawa (Yogyakarta, Surakarta) } \\
\text { kontemporer. }\end{array}$ \\
\hline \multirow[t]{2}{*}{$\begin{array}{l}\text { Tokoh-tokoh utama; Rama, Sinta, } \\
\text { Rahwana, dan Lakshmana. }\end{array}$} & $\begin{array}{l}\text { Tokoh-tokoh utama; Setyo (representasi } \\
\text { Rama), Siti (representasi Sinta), Ludiro } \\
\text { (reprentasi Rahwana). }\end{array}$ \\
\hline & $\begin{array}{l}\text { Tokoh Pengawal (berperan mirip } \\
\text { Lakshmana, tetapi berbeda latar belakang). } \\
\text { Penciptaan tokoh baru Dalang (pewarta). }\end{array}$ \\
\hline $\begin{array}{l}\text { Rama menolong kaum pertapa dari } \\
\text { gangguan para raksasa, dalam } \\
\text { pertempuran melawan Rahwana, dia } \\
\text { dibantu oleh pasukan kera di bawah } \\
\text { pimpinan Sugriwa yang pernah } \\
\text { ditolongnya. Rama membunuh Rahwana } \\
\text { dengan panah saktinya. }\end{array}$ & $\begin{array}{l}\text { Setyo bersimpati kepada pedagang kecil } \\
\text { yang tertindas oleh kelompok dominan } \\
\text { yang dipimpin Ludiro kemudian Setyo } \\
\text { memimpin kelompok tertindas ini untuk } \\
\text { melakukan perlawanan. Setyo membunuh } \\
\text { Ludiro menggunakan pisau. }\end{array}$ \\
\hline $\begin{array}{l}\text { Sinta diculik Rawana. Sinta lolos dalam } \\
\text { ujian kesetiaan cintanya kepada Rama. }\end{array}$ & $\begin{array}{l}\text { Siti yang menghampiri Ludiro. Siti dibunuh } \\
\text { oleh Setyo untuk tetap dimiliki cinta atau } \\
\text { "hatinya" oleh suaminya tersebut. }\end{array}$ \\
\hline
\end{tabular}

\section{$7 \quad$ Kesimpulan dan Saran}

Hibriditas medium merupakan pilihan medium ungkap dan gaya ungkap yang menjadi ekspresi sineas. Hibriditas medium mendekonstruksi penuturan naratif visual film Opera Jawa dimana elemen-elemen visual menjadi petanda-petanda dekonstruktif yang mengkonstruksi pesan dan makna. Lewat film Opera Jawa, Garin Nugroho melakukan dekonstruksi terhadap: tokoh-tokoh, ruang, pesan dan makna, serta narasi, termasuk judul karya, dari epik Ramayana karya Walmiki yang menjadi rujukannya. 
Pesan dan makna pada film Opera Jawa ini merefleksikan persoalan gender, feminisme, dominasi maskulinitas, dominasi kekuasaan, pertentangan kelas, dan kapitalisme di tengah kehidupan masyarakat patriarkal dalam sosio-budaya Jawa kontemporer. Garin mengaktualisasikan epik Ramayana yang menjadi rujukan ke dalam konteks masyarakat Jawa kontemporer, sekaligus memanfaatkan kepopuleran cerita rujukan tersebut menjadi kendaraan untuk aktualisasi ekspresi pribadi dalam konteks estetika posmodern. Metafora eufemistis yang bersifat elutif merupakan gaya ungkap yang digunakan dalam dekonstruksi terhadap pesan dan makna. Dengan keragaman tingkat dan jenis referensi pengetahuan dan pengalaman penonton, sifat elutif ini memberikan peluang wacana baru bagi stimulasi ketertarikan penontonnya.

Gaya ungkap baru dengan membongkar sekat-sekat pembatas diantara berbagai medium dalam mengkolaborasikannya adalah bentuk eksperimental yang bukan tanpa resiko. Akan tetapi gagasan ini tetap menarik sebagai sebuah tawaran dan wacana pengkayaan khasanah budaya serta penjelajahan tata ungkap artistik. Ekspresi sineas dalam menyampaikan ide, gagasan, dan konsep ini berupa idiom estetik parodi. Idiom estetik parodi pada dialogisme tekstual antara teks epik Ramayana dengan teks film Opera Jawa sebagai bentuk kritik atau sindiran atau bahkan justru merupakan bentuk pengambilan keuntungan dari kemasyhuran teks rujukan oleh sang sineas.

Film sebagai media audio-visual memberikan kemungkinan interpretasi pesan dan makna yang luas. Film ini menjadi media komunikasi antara sineas dengan penontonnya. Berkaitan dengan hal tersebut, berikut beberapa saran: (a) bagi penonton dan masyarakat umum; Diperlukan referensi konteks keilmuan yang mencukupi, berkaitan dengan misi yang diusung dan gaya ungkap yang ditawarkan sineas. Di samping itu diperlukan pendekatan akademis dalam konteks posmodern, termasuk ke dalamnya sistem pembacaan film untuk penonton dan masyarakat umum agar sampai kepada pemahaman pesan dan pemaknaan sebuah film; (b) bagi stakeholders perfilman; Di samping upaya peningkatan kualitas teknis dan upaya peningkatan kualitas isi pesan, sangat terbuka kemungkinan untuk melakukan eksplorasi pemilihan dan penggunaan medium. Konteks posmodern memberikan wacana berupa pelenturanpelenturan ditawarkan oleh banyak medium yang berasal bidang seni budaya lain. Seperti halnya yang ditawarkan (pelaku) seni instalasi dengan pelenturannya yang tinggi, memungkinkan medium ini untuk dieksplorasi dan menjadikannya sebagai elemen visual dalam film. Eksplorasi medium memberikan peluang dan kemungkinan-kemungkinan gaya ungkap baru; (c) bagi bidang akademik; Penelitian ini menitikberatkan kepada aspek visual dan gerak dan pendekatan estetika posmodern melalui analisis semiotika film dan pembacaan dekonstruksi dengan teknik deskriptif interpretatif. Masih terbuka 
peluang dan kemungkinan penelitian lanjutan terhadap Film ini atau film sejenisnya melalui perspektif atau metode lain.

\section{Referensi}

[1] Widaryanto, FX. 2005. Kritik Tari: Gaya, Struktur, dan Makna, Bandung: Penerbit Kelir.

[2] Piliang, Y.A. 2003. Hipersemiotika: Tafsir Cultural Studies atas Matinya Makna, Yogyakarta: Jalasutra.

[3] Ellya, Z. 2003. Kajian Desain Terhadap Hibriditas dalam Gaya Jilbab di Indonesia: Tesis Magister Desain, Fakultas Seni Rupa dan Desain, Institut Teknologi Bandung (ITB).

[4] Walker, J.A. \& Chaplin, S. 1997. Visual Culture: An Introduction, Manchester: Manchester University Press.

[5] Barker, C. 2009. Cultural Studies, Teori dan Praktik, Penterjemah: Nurhadi, Yogyakarta: Kreasi Wacana.

[6] Danesi, M. 2004. Pesan, Tanda, dan Makna: Buku Teks Dasar Mengenai Semiotika dan Teori Komunikasi, Penterjemah: Evi Setyarini dan Lusi Lian Piantari, Yogyakarta: Jalasutra.

[7] Wija atau Bija, Yayasan Bali Galang, http://www.babadbali.com/ canangsari/bija.htm (20 February 2012).

[8] Soeradiredja, D.M.A., A-Z Menyingkap Makna Simbol Kuno. http://sosbud.kompasiana.com/2011/03/30/a-z-menyingkap-maknasimbol-kuno-352783.html (20 February 2012).

[9] Darmaprawira, S. 2002. Warna: Teori dan Kreativitas Penggunaannya, Edisi ke-2, Bandung: Penerbit ITB. 